\title{
Effect of Ultrasound Treatment Prior to Vacuum and Modified Atmosphere Packaging on Microbial and Physical Characteristics of Fresh Beef
}

\author{
Mandour H. Abdalhai, Mohanad Bashari, Camel Lagnika, Qian He, Xiulan Sun* \\ State Key Laboratory of Food Science and Technology, School of Food Science and Technology, Jiangnan University, Lihu Road, \\ Wuxi, China \\ *Corresponding author: sxlzzz@jiangnan.edu.cn, mabdalhai1@hotmail
}

Received April 29, 2014; Revised June 15, 2014; Accepted June 17, 2014

\begin{abstract}
The effects of ultrasound treatment prior to the vacuum package and modified atmosphere package on physical, microbial and sensory characteristics of beef meat stored at refrigerator $4^{\circ} \mathrm{C}$. Sampling was carried out on the $0,3^{\text {rd }}, 6^{\text {th }}, 10^{\text {th }}, 14^{\text {th }}, 18^{\text {th }}$ and $22^{\text {th }}$ day of storage. The initial bacteria loading was the slight same on all meat samples and microbial load increase over time. The extension of shelf life may be due to the synergistic effect of integration of two types of preservation used on the microbiological and physicochemical characteristics of meat. Both these hurdles could prolong and delay microbial growth or suppress the final counts of the spoilage microorganisms in comparison with the 'control' samples. Ultrasound combined with MAP showed the highest panelists acceptance during the storage. Results showed deterioration in the properties of the microbial and physical characteristics quality of the control samples compared with other samples during the storage.
\end{abstract}

Keywords: fresh beef, Ultrasound, modified atmosphere package, vacuum package, Microbial and Physical properties

Cite This Article: Mandour H. Abdalhai, Mohanad Bashari, Camel Lagnika, Qian He, and Xiulan Sun, "Effect of Ultrasound Treatment Prior to Vacuum and Modified Atmosphere Packaging on Microbial and Physical Characteristics of Fresh Beef." Journal of Food and Nutrition Research, vol. 2, no. 6 (2014): 312-320. doi: 10.12691/jfnr-2-6-8.

\section{Introduction}

Due to increased demands for greater stringency in relation to hygiene and safety of fresh and processed meat products with natural flavor and taste, free from additives and preservatives, coupled with ever-increasing demands for extensions product shelf-lives and the requirement to meet consumer expectations in relation to convenience and quality, new innovations, technologies, and concepts of nonthermal has continue to emerge to meet and satisfy expectations.

Meat has been a major part of the human diet throughout history. Meat has a good digestibility and a balanced composition of essential amino acids and is a great source of proteins, vitamins and minerals. In a relative small serving the daily requirement of protein and amino acids can be reached [1]. The diverse nutrient composition of meat makes it an ideal environment for the growth and propagation of meat spoilage micro-organisms and common food-borne pathogens. It is therefore essential that adequate preservation technologies are applied to maintain its safety and quality [2]. Having better meat quality is the basic concern of all meat producer and processor.

Ultrasound is a form of energy generated by sound (really pressure) waves of frequencies that are too high to be detected by human ear, i.e. above $16 \mathrm{kHz}$ [3]. It can be utilized in many industrial applications including food. Ultrasound is one of the emerging technologies that were developed to minimize processing, maximize quality and ensure the safety of food products. Ultrasound is applied to impart positive effects in food processing such as improvement in mass transfer, food preservation, assistance of thermal treatments and manipulation of texture and food [1]. High energy (high power, highintensity) ultrasound uses intensities higher than 1 $\mathrm{W} \cdot \mathrm{cm}-2$ at frequencies between 20 and $500 \mathrm{kHz}$, which are disruptive and induce effects on the physical, mechanical or chemical/biochemical properties of foods [4]. While a frequency of about $20 \mathrm{kHz}$ is usually applied for microbial inactivation, the resistance to ultrasound treatment of spores, and Gram positive and coccal cells are higher than vegetative, Gram-negative and rod-shaped bacteria [5].

Recently, a great deal of interest has been shown in the potential benefits of ultrasound, which has attracted considerable interest in food science and technology due to its promising effects in food processing and preservation [6]. However, limited studies on ultrasound of beef meat have appeared in literature.

Vacuum packaging (VP) under chilled conditions has proved very effective in extending the shelf life of perishable foods, such as fresh meat and meat products, 
and preventing the growth of food-borne pathogens [7]. Color, lipid oxidation, and microbial criteria are the most important quality criteria for storage of fresh red meat. It is well known that packaging makes food more convenient and gives the food greater safety assurance from microorganisms, biological and chemical changes so that the packaged foods may have a longer shelf life [8]. The changes may influence affect the contribution of different members of microbial association and as a consequence, an extension of shelf life can be achieved. Despite the extended shelf life of refrigerated products stored under vacuum pack, modified atmosphere packaging conditions; there is an increased concern about the growth survival of microaerophilic psychrotrophic pathogens [9].

Over the past number of years much research has focused on the influence of modified atmosphere packaging (MAP) on meat quality attributes and the purchasing preferences of consumers, the modified atmosphere packaging is a technique, which is widely used to extend the shelf-life and to improve the quality of perishable foods including meat and meat products stored at refrigeration temperatures or below [10]. These packaging methods have changed distribution patterns since their introduction more than 30 years ago.

The main objective of the present study was to investigation the effects of ultrasound treatments prior to vacuum package (VP) and modified atmosphere package (MAP) on the preservation and overall quality of fresh beef meat during chilled storage. The effect of all these treatments was examined by microbial analysis, sensory evaluation and physical characteristics.

\section{Material and Methods}

\subsection{Sample Treatment and Storage Conditions}

Fresh meat was removed from beef carcasses at $24 \mathrm{~h}$ post-mortem collected from a local supermarket (butcher) (Wuxi, Jiangsu province, China). A meat samples (7 kg) were transported to the laboratory on ice cooler box during less than $1 \mathrm{~h}$. Cutting was carried out at ambient temperature with a sterile sharp knife and the fresh cut beef was individually placed in polyethylene tray $(10$ x 6 x $2 \mathrm{~cm})$. Meat samples were selected at random and subjected to the following treatments:

Control: Soaked in sodium acetate solution then packaged.

US-VP: Ultrasound in sodium acetate solution combined with vacuum package.

US-MAP: Ultrasound in sodium acetate solution combined with MAP.

VP: soaked in sodium acetate solution combined with vacuum package.

MAP: Soaked in sodium acetate solution combined with MAP

The meat samples were soaked for $10 \mathrm{~min}$ in a chilled aqueous solution of $0.2 \mathrm{M}$ sodium acetate at $4^{\circ} \mathrm{C}$, and then subjected to the different treatments.

Vacuum- packed meat was stored in the absence of oxygen. The fresh beef was individually placed in polypropylene trays for MAP and plastic bag polyethylene for vacuum-packaged using a vacuum-packaging machine
(Hu Yue Pack Aging Machinery plant, China) and then stored at refrigerator.

The ultrasound experimental apparatus used for this work consisted of ultrasound generators probe, relatively cheap, simple and safety, (JYD-900L, Shanghai Zhixin Co., Ltd. China), which can deliver a maximum power of $100 \mathrm{~W}$ at $25 \mathrm{kHz}$, equipped with a thermometer to measure the temperature. Ice bath was adopted to keep the sample temperature at a constant. Samples were placed in $1000 \mathrm{~mL}$ glass beaker content $700 \mathrm{~mL}$ of a sodium acetate concentration of $0.2 \mathrm{M}$ at $4^{\circ} \mathrm{C}$ and ultrasound for $10 \mathrm{~min}$ with $50 \mathrm{~W}$ at $25 \mathrm{kHz}$. After the ultrasound treatment, samples were immediately divided into two groups, the first group packaged by vacuum packaging, and the second group was packaged by MAP. MAP experiments were conducted using a MAP-H360 machine (Senrui Fresh Care Equipment, Suzhou, China) creating gas mixture consisting of $60 \% \mathrm{CO}_{2}$ and $40 \% \mathrm{~N}_{2}$ [11].

All samples were storage in refrigerator at $4^{\circ} \mathrm{C}$. Two packs from each group were randomly selected and physical and microbiological analysis have been carried out on the following days of storage period, $0,3^{\text {th }}, 6^{\text {th }}, 10^{\text {th }}$, $14^{\text {th }}, 18^{\text {th }}$, and $22^{\text {th }}$ days. All measurements were done in triplicates from each treatment group.

\section{2. pH Measurement}

$\mathrm{pH}$ was measured according to the method described by [12], with slight modifications. Sample (10 g) was added to $100 \mathrm{~mL}$ of distilled water and then homogenized by stomacher for $1 \mathrm{~min}$. Sample left for $30 \mathrm{~min}$ and then filtrated supernatant, $\mathrm{pH}$ value of the resulted supernatant was measured used $\mathrm{pH}$ meter (Mettler-Toledo instruments, Delta 320, Shanghai, China).

\subsection{Weight Loss}

Weight loss was measured according to the method describe by [13] with slide modified. Beef meat was weighted before storage at day 0 . Samples were removed from packaging and gently blotted with tissue paper prior to weighing. Drip loss was determined by measuring the weight loss during storage and calculated as

$$
\text { Weight loss } \%=\frac{\left[\begin{array}{l}
\text { weightonday }(0) \\
- \text { weightonday }(n)
\end{array}\right]}{\text { weighton Day }} * 100
$$

\subsection{Cooking Loss}

The loss due to cooking was determined for each treatment according to the method described by [14]. Beef sample (20 g) was weighted then placed in plastic bag and heated in a water bath at $75^{\circ} \mathrm{C}$ for $20 \mathrm{~min}$. Cook-out was drained and the cook mass was allowed to cool for approximately $5 \mathrm{~min}$ at room temperature and weighted to determine differences for meat before and after cooking. The cooking loss was calculated according to the following equation:

$$
\text { cooking loss } \%=\frac{\left(\begin{array}{c}
\text { Actual weight } \\
\text {-cooked mass weight }
\end{array}\right)}{\text { Actual weight }} * 100
$$




\subsection{Water-holding Capacity}

Water-holding capacity (WHC) of fresh beef meat samples was analyzed using the bag method as described by [15]. A slice of meat was hung in a plastic bag and allowed to stand for $48 \mathrm{~h}$ at $4{ }^{\circ} \mathrm{C}$. Drip loss was calculated as the difference in weight before and after hanging and reported as percent drip loss of initial weight. WHC was expressed as percentage of moisture content to meat, according to the following equation:

$$
\text { WHC }=\frac{(\text { Initial weight }- \text { Final weight })}{\text { Initial weight }} * 100
$$

\subsection{Color}

Surface color of fresh beef was measured instrumentally by a Hunter lab digital colorimeter (TCPIIG system, Beijing Optical Instrument Co. Ltd., China) using CIE color parameters L* (light/dark) a* (red/ green) and $b^{*}$ (yellow/blue) values. The color of foods has been measured in $\mathrm{L}^{*} \mathrm{a} * \mathrm{~b}^{*}$. The $\mathrm{L}^{*} \mathrm{a} \mathrm{b}^{*}$, or CIE Lab, color space is an international standard for color measurements, adopted by the Commission Internationaled Eclairage (CIE) in 1976 [16]. Color measurements were taken from four different positions.

The instrument was calibrated with black and white standard plates before the analysis. Each data point was the mean of four replications. The following calculations were done to determine the attribute of $\Delta \mathrm{E}$ indicates the degree of overall color change [17].

$$
\begin{gathered}
\Delta L^{*}=L_{\text {sample }}^{*}-L_{\text {standard }}^{*} ; \Delta a^{*}=a_{\text {sample }}^{*}-a_{\text {standard }}^{*} ; \\
\Delta b^{*}=b_{\text {sample }}^{*}-b_{\text {standard }}^{*} \\
\Delta E=\sqrt{\left(\Delta L^{* 2}+\Delta a^{* 2}+\Delta b^{* 2}\right)} .
\end{gathered}
$$

Where $\Delta \mathrm{E}$ indicates the degree of overall color change in comparison to color values of an ideal fresh beef meat. $\mathrm{L}^{*}$ sample, $\mathrm{a}^{*}$ sample and $\mathrm{b}_{\text {sample }}$ measure direct from sample and $\mathrm{L}^{*}$ standard, $\mathrm{a}^{*}$ standard and $\mathrm{b}^{*}$ standard for standard of instrument. $\left(\Delta L^{* 2}+\Delta a^{* 2}+\Delta b^{* 2}\right)$ it is a square difference between the measured value and the standard value.

\subsection{Texture}

Texture measurements were obtained for individual samples using texture profile analysis (TPA) with a texture analyzer (TA-XT2i, Stable Micro Systems Ltd., $\mathrm{UK})$. The textural parameters of hardness (N), maximum force required for the initial compression of the sample, gumminess, the strength of internal bonds making up the body of the product, adhesiveness $(\mathrm{N} \times \mathrm{mm})$, area under the abscissa post initial compression; and chewiness $(\mathrm{N} \times$ $\mathrm{mm}$ ), the required work to masticate the sample were calculated. Every slice was then subjected to a two-cycle compression test with a $35 \mathrm{~mm}$ in diameter cylindrical probe. All analyses were performed in triplicate at room temperature $25^{\circ} \mathrm{C}$ and the mean and standard deviation was calculated.

\subsection{Enumeration of Microorganism's Populations by Plate Counting}

Twenty five grams of each sample were aseptically weighed and then homogenized in $225 \mathrm{~mL}$ of sterile peptone saline (8 $\mathrm{g} / \mathrm{L} \mathrm{NaCl}, 1 \mathrm{~g} / \mathrm{L}$ peptone), in a Stomacher Lab-Blender (scientz 09) for $2 \mathrm{~min}$ at room temperature $\left(25^{\circ} \mathrm{C}\right)$. Further decimal dilutions $10^{-2}, 10^{-3}$, $10^{-4}$ and $10^{-5}$ were prepared in tubes $(1.0 \mathrm{~mL}$ with $9.0 \mathrm{~mL}$ of $0.1 \%$ peptone water) and the following analyses were carried out on duplicate agar plates, mesophilic aerobic bacterial counts on plate count agar (incubated for $48 \mathrm{~h}$ at $30{ }^{\circ} \mathrm{C}$ ), lactic acid bacteria on Man Rogosa Sharpe (MRS) agar (incubated for $48 \mathrm{~h}$ at $30{ }^{\circ} \mathrm{C}$ ) in an anaerobic jar, Enterobacteriaceae on violet red bile glucose agar (VRBGA) incubated at $37^{\circ} \mathrm{C}$ for $24 \mathrm{~h}$. Then the number of colony forming units per gram (CFU/g-1) was determined.

\subsection{Sensory Evaluation}

Sensory evaluations were carried out by eight-member panel semi-trained of four males and four female's panelist consisting of students of the School of food Sciences and Technology, Jiangnan University. The sensory parameters including color, appearance, flavor, texture and overall acceptance were evaluated using a nine-point hedonic scale, where the extremes corresponded to $9=$ liked extremely, $8=$ liked very much, 7 = liked moderately, 6 = liked slightly, 5 = neither liked nor disliked, 4 = disliked slightly, 3 = disliked moderately, 2 = disliked much, and 1 = disliked extremely.

\subsection{Statistical Analysis}

All experiments described above were made at least in triplicate for each sample. The data presented were the means and standard deviations of each experiment. The experimental data were analyzed using the ANOVA and Duncan's multiple range tests by the SPSS 16.0 (SPSS Inc., Chicago, USA) computer program. Unless otherwise noted in the text, a $\mathrm{P}<0.05$ level was used where values were considered as being significantly different.

\section{Results and Discussion}

\section{1. pH Analysis}

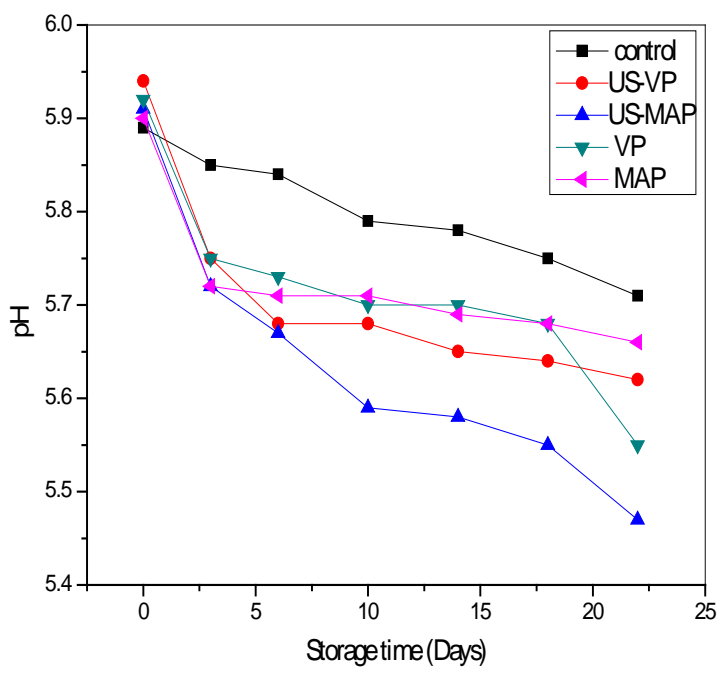

Figure 1. $\mathrm{pH}$ of meat stored after different types of treatments during storage at $4{ }^{\circ} \mathrm{C}$ for 22 days 
$\mathrm{pH}$ is most commonly measured in fresh meat because it effects technological ability, and most sensory traits. The $\mathrm{pH}$ value of beef meat was examined and results are presented in (Figure 1). The $\mathrm{pH}$ values of all treatments were decreased during storage period. In this study, treatments changed the $\mathrm{pH}$ from $5.891 \pm 0.02$ to $5.79 \pm$ $0.03,5.94 \pm 0.03$ to $5.62 \pm 0.11,5.91 \pm 0.02$ to $5.47 \pm 0.12$, $5.92 \pm 0.02$ to $5.55 \pm 0.01$ and $5.90 \pm 0.01$ to $5.66 \pm 0.01$ for samples control, US-VP, US-MAP, VP and MAP, respectively. This result was in good agreement with that observed by [18]. They found that the $\mathrm{pH}$ reduced in control sample from (5.76 to 5.52). In addition, [7] also found that, the mean of the $\mathrm{pH}$ values in fresh beef vacuum package was decreased during storage at $2^{\circ}$ and $8^{\circ} \mathrm{C}$ to final values of $5.17 \pm 0.03$ and $5.24 \pm 0.02$, respectively, the drop in $\mathrm{pH}$ values observed in meat samples may be attributed to the selective growth of microorganisms especially the lactic acid bacteria, which may also have contributed to the inhibition of gramnegative meat-borne organisms [7].

The control group was showed a slightly higher difference than other groups. Control sample showed $\mathrm{pH}$ value in a range between (5.89 \pm 0.02 to $5.71 \pm 0.03)$. At $\mathrm{pH}$ value above 6.0 leads to a dark red color in meat, and this is probably associated with growth of microorganisms during storage, with contaminate meat there can be a change in color often a fading or darkening the structure of the myoglobin change. The $\mathrm{pH}$ may interact with other factors such as water activity, salt, temperature, oxidereduction potential, and preservatives to inhibit growth of pathogenic microorganisms and deteriorate. The results showed no significant difference in the beginning of storage ( 0 and 3 ) days. The big difference emerged after the 6th day. From $10^{\text {th }}$ to $22^{\text {th }}$ day, the US-MAP and USVP samples showed significant difference $(\mathrm{P}<0.05)$ compared to control samples.

\subsection{Weight Loss}

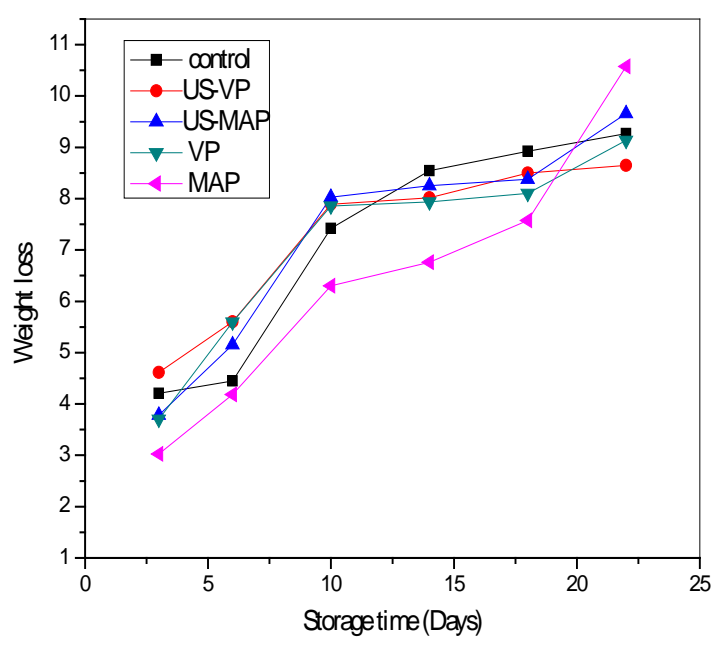

Figure 2. Weight loss of meat stored after different types of treatments during storage at $4{ }^{\circ} \mathrm{C}$ for 22 days

Drip loss is an important quality criterion for the meat processing industry and also for the consumer. It was increased over time for all beef samples (Figure 2), an increase in weight losses is commercially unacceptable because it leads to loss in the nutrients, the results showed that, the drip loss was significantly $(\mathrm{P}<0.05)$ increased with increases in storage periods, the highest drip loss was observed on day 22 in US-MAP and MAP samples. This result was in good agreement with that observed by [15] and [19]. Zakrys-Waliwander et al (2011) reported, weight loss increased over time for beef steaks packaged under modified atmosphere packaging conditions, and found that weight loss in pork was significantly different $(\mathrm{P}<0.05)$ on day 14 in comparison to vacuum packaged samples.

\subsection{Water-holding Capacity}

WHC is important attribute of meat and meat products. It is the ability to hold moisture and other juices in the meat both before and after treatments. Therefore, it uses to measure how well the juices were retained in meat. The effect of different treatments on WHC of beef meat was analyzed and the results are presented in Figure 3. Result showed that, for all samples studied, there was no significant different $(\mathrm{P}<0.05)$ in WHC, however, after the $6^{\text {th }}$ day of storage WHC slightly decreased. WHC of the US-MAP and MAP treatments was higher than that for control during 3-6 days of storage, after the $6^{\text {th }}$ day of storage WHC of the US-MAP and MAP treatments became lower than that for control. On the other hand, WHC of the US-VP treatment was lower than that for control during all days of storage, except that at $22^{\text {th }}$ day of storage. It's expected that, the above observation was due to decreased of $\mathrm{pH}$ values of all treatment during storage days. It was reported that, WHC influences by several factors such as $\mathrm{pH}$ [20]. It was also reported that $\mathrm{pH}$ above 6.00 increased WHC [21].

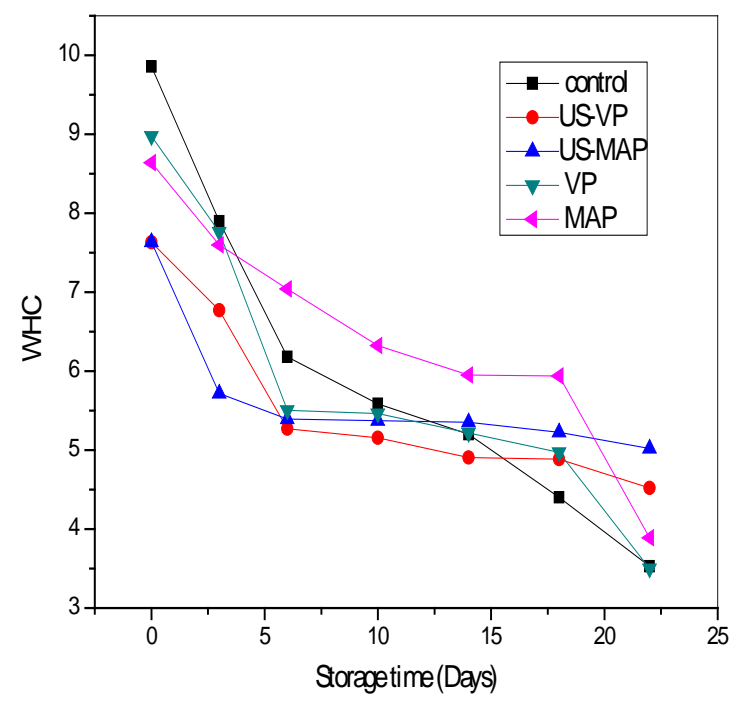

Figure 3. Water Holding Capacity of meat stored after different types of treatments during storage at $4^{\circ} \mathrm{C}$ for 22 days

\subsection{Cooking LOSS}

Cooking loss refers to the reduction in weight of beef during the cooking process [22]. Values of cooking loss measurements of samples are shown in Figure 4. All samples showed a decrease in cooking loss over time. In fact, the high value of cooking loss was observed in the control sample. High cooking loss leads to loss of several essential minerals and vitamins which results in the deterioration of beef nutritional quality. This could be attributed to the high loss of moisture and fat during cooking. Ratio cooking loss is associated with the amount of fat in the meat, the higher the proportion of fat in the 
meat. In this study ratio of cooking loss was high. At the end of the storage period ( $22^{\text {th }}$ day) samples were different in cooking loss. The highest cooking loss was observed in control sample, while the lowest cooking loss was found in MAP sample The decrease in cooking loss as ageing increased was as expected since enzymatic reactions by endogenous enzymes, such as collagenase which are produced by bacteria within beef or by ionic solubilisation [23]. [24] was reported that, the low intensity ultrasound treatment $\left(1.55 \mathrm{Wcm}^{-2}\right.$ for 8.16 or $\left.24 \mathrm{~min}\right)$ of vacuum packaged beef muscles had no effect on cooking loss. Wicklund et al. (2005) reported that enhanced beef strip loin steaks had less cooking loss on day 7 of storage but not on day 14, 21, or 28 than non enhanced steaks.

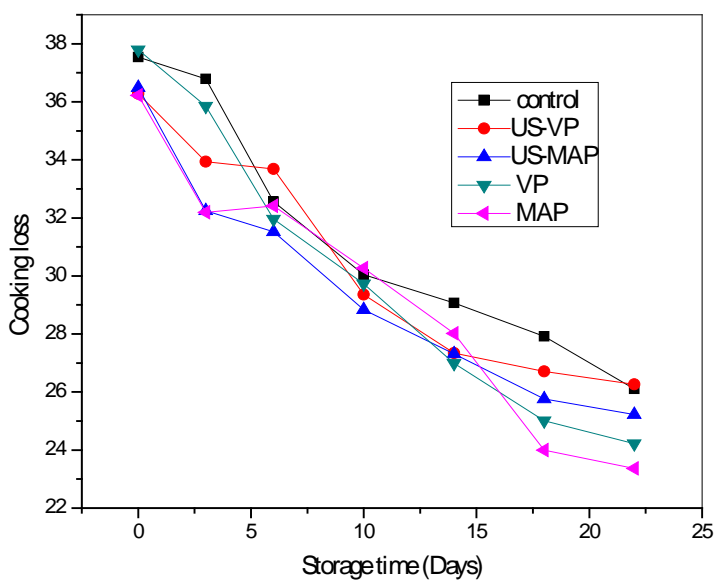

Figure 4. Cooking loss of meat stored after different types of treatments during storage at $4{ }^{\circ} \mathrm{C}$ for 22 days

\subsection{Color}

In the case of beef, purchasing decisions are influenced by color more than by any other quality factor, because consumers relate the bright cherry red color of oxymyoglobin to freshness and wholesomeness, while the brown color of metmyoglobin is considered undesirable.
The apparent color is affected by the amount of water in or on the fresh meat.

Changes in color values of beef meat during storage, evolution of $L^{*}, a^{*}, b^{*}$ and $\Delta E$ values is shown in Table 1 . The effect of treatments and storage on $\mathrm{L}^{*}$ value of fresh meat samples were statistically significan different. Jakobsen and Bertelsen (2000) were reported that there were no significant statistical and visual differences between the $\mathrm{a}^{*}$ values of MAP samples and the redness was kept until the $14^{\text {th }}$ day of storage with these gas compositions. Results of $\mathrm{a}^{*}$ redness was showed that, there was no significant difference in the beginning of storage as well as after three days, onset difference after six days of storage. Instrumental a* values for all samples displayed a not significant $(\mathrm{P}<0.05)$ positive correlation with days, indicated a decrease in the red color of samples over time. John et al. (2005) reported that steaks packed under high oxygen had a desirable red color on day 7 of storage, but some browning was evident by day 14 and steaks were completely brown and unappealing by day 21 . In most period of storage control sample showed differing significant from the other samples. The presence of large standard deviations during the measurements, this situation depends on to the regional differences in the redness of samples because of the usage of oxygen during the storage and oxygen deficiency until the end of storage period. With the advancement of private storage period in control sample, high ultimate $\mathrm{pH}$ can effect the color stability of fresh meat because it effects enzyme activity and the rate of oxygenation. Reducing enzymes are necessary to convert metmyoglobin back to oxymyoglobin [2]. $\mathrm{L}^{*}$ showed a significant different after three days of storage, moral difference appeared in the control sample during the storage period. Many factors effect the occurrence of premature browning, persistent pink, and color reversion. The main factors that effect the color include: pigment concentration, chemical state of the pigment, $\mathrm{pH}$, reducing activity, meat respiration rate (oxygen consumption), time, temperature (cooking and storage), packaging system employed and microbial load.

Table 1. Effect of different treatments and packaging method on Hunter color values

\begin{tabular}{|c|c|c|c|c|c|c|c|}
\hline & 0 day & 3 days & 6 days & 10 days & 14 day & 18days & 22 days \\
\hline \multicolumn{8}{|l|}{$\mathbf{L}^{*}$} \\
\hline Control & $46.93 \pm 0.93^{\mathrm{a}}$ & $46.84 \pm 1.42^{\mathrm{a}}$ & $42.36 \pm 1.15^{\mathrm{ab}}$ & $40.58 \pm 1.15^{\mathrm{ab}}$ & $37.12 \pm 0.77^{\mathrm{a}}$ & $36.37 \pm 0.82^{\mathrm{b}}$ & $36.08 \pm 0.52^{b}$ \\
\hline US-VP & $47.93 \pm 095^{\mathrm{a}}$ & $45.99 \pm 1.92^{\mathrm{a}}$ & $43.18 \pm 0.83^{\mathrm{ab}}$ & $42.08 \pm 1.76^{\mathrm{ab}}$ & $40.06 \pm 1.19^{b}$ & $38.87 \pm 1.26^{\mathrm{ab}}$ & $38.86 \pm 1.26^{\mathrm{b}}$ \\
\hline US-MAP & $47.98 \pm 0.94^{\mathrm{a}}$ & $46.95 \pm 1.36^{\mathrm{a}}$ & $43.46 \pm 1.33^{\mathrm{a}}$ & $42.73 \pm 1.14^{\mathrm{a}}$ & $41.15 \pm 1.36^{\mathrm{b}}$ & $39.48 \pm 1.51^{\mathrm{a}}$ & $38.84 \pm 1.31^{\mathrm{a}}$ \\
\hline VP & $48.00 \pm 1.88^{\mathrm{a}}$ & $47.91 \pm 1.89^{\mathrm{a}}$ & $40.73 \pm 0.75^{\mathrm{ab}}$ & $40.02 \pm 1.50^{\mathrm{b}}$ & $40.05 \pm 0.94^{b}$ & $37.91 \pm 1.34^{\mathrm{ab}}$ & $37.77 \pm 1.27^{\mathrm{ab}}$ \\
\hline MAP & $47.98 \pm 1.64^{\mathrm{a}}$ & $45.985 \pm 1.38^{\mathrm{a}}$ & $40.64 \pm 1.58^{\mathrm{ab}}$ & $40.11 \pm 1.81^{\mathrm{b}}$ & $40.15 \pm 1.15^{\mathrm{b}}$ & $38.07 \pm 1.52^{\mathrm{ab}}$ & $38.74 \pm 1.43^{\mathrm{b}}$ \\
\hline \multicolumn{8}{|l|}{$\mathbf{a}^{*}$} \\
\hline Control & $6.12 \pm 1.13^{\mathrm{a}}$ & $6.12 \pm 1.13^{\mathrm{a}}$ & $5.47 \pm 0.87^{\mathrm{a}}$ & $5.12 \pm 0.71^{\mathrm{a}}$ & $4.08 \pm 0.97^{\mathrm{a}}$ & $4.49 \pm 0.86^{\mathrm{a}}$ & $5.23 \pm 1.34^{\mathrm{a}}$ \\
\hline US-VP & $6.37 \pm 1.45^{\mathrm{a}}$ & $6.38 \pm 1.45^{\mathrm{a}}$ & $6.20 \pm 1.38^{\mathrm{a}}$ & $6.096 \pm 1.59^{\mathrm{a}}$ & $5.91 \pm 1.40^{\mathrm{a}}$ & $5.50 \pm 1.87^{\mathrm{a}}$ & $5.15 \pm 1.04^{\mathrm{a}}$ \\
\hline US-MAP & $6.31 \pm 1.39^{\mathrm{a}}$ & $6.30 \pm 1.28^{\mathrm{a}}$ & $6.18 \pm 0.86^{\mathrm{a}}$ & $5.76 \pm 1.62^{\mathrm{a}}$ & $5.97 \pm 1.32^{\mathrm{a}}$ & $5.44 \pm 1.07^{\mathrm{a}}$ & $5.21 \pm 0.76^{\mathrm{a}}$ \\
\hline VP & $6.25 \pm 1.36^{\mathrm{a}}$ & $6.25 \pm 1.25^{\mathrm{a}}$ & $5.59 \pm 1.36^{\mathrm{a}}$ & $5.45 \pm 1.35^{\mathrm{a}}$ & $5.19 \pm 0.91^{\mathrm{a}}$ & $4.93 \pm 0.75^{\mathrm{a}}$ & $4.01 \pm 1.38^{\mathrm{a}}$ \\
\hline MAP & $6.27 \pm 0.87^{\mathrm{a}}$ & $6.27 \pm 0.86^{\mathrm{a}}$ & $6.13 \pm 0.58^{\mathrm{a}}$ & $5.98 \pm 1.50^{\mathrm{a}}$ & $5.51 \pm 0.92^{\mathrm{a}}$ & $5.32 \pm 1.03^{\mathrm{a}}$ & $4.93 \pm 1.13^{\mathrm{a}}$ \\
\hline \multicolumn{8}{|l|}{$\mathbf{b}^{*}$} \\
\hline Control & $7.05 \pm 1.52^{\mathrm{a}}$ & $6.44 \pm 0.91^{\mathrm{a}}$ & $5.98 \pm 1.05^{\mathrm{a}}$ & $5.86 \pm 0.84^{\mathrm{a}}$ & $5.13 \pm 1.59^{\mathrm{a}}$ & $5.08 \pm 0.97^{\mathrm{a}}$ & $4.81 \pm 1.77^{\mathrm{a}}$ \\
\hline US-VP & $7.09 \pm 1.37^{\mathrm{a}}$ & $7.04 \pm 1.07^{\mathrm{a}}$ & $6.85 \pm 1.26^{\mathrm{a}}$ & $6.94 \pm 0.91^{\mathrm{a}}$ & $6.23 \pm 1.01^{\mathrm{a}}$ & $6.18 \pm 1.42^{\mathrm{a}}$ & $8.53 \pm 1.45^{\mathrm{a}}$ \\
\hline US-MAP & $6.97 \pm 1.51^{\mathrm{a}}$ & $7.06 \pm 1.29^{\mathrm{a}}$ & $7.01 \pm 0.44^{\mathrm{a}}$ & $7.05 \pm 0.67^{\mathrm{a}}$ & $6.79 \pm 1.28^{\mathrm{a}}$ & $6.40 \pm 1.04^{\mathrm{a}}$ & $8.83 \pm 0.56^{\mathrm{b}}$ \\
\hline VP & $6.95 \pm 1.36^{\mathrm{a}}$ & $6.33 \pm 1.61^{\mathrm{a}}$ & $6.30 \pm 1.55^{\mathrm{a}}$ & $6.28 \pm 0.86^{\mathrm{a}}$ & $6.18 \pm 1.48^{\mathrm{a}}$ & $5.94 \pm 0.92^{\mathrm{a}}$ & $6.05 \pm 0.88^{\mathrm{ab}}$ \\
\hline MAP & $6.85 \pm 1.31^{\mathrm{a}}$ & $6.49 \pm 0.84^{\mathrm{a}}$ & $6.53 \pm 0.71^{\mathrm{a}}$ & $6.08 \pm 1.22^{\mathrm{a}}$ & $6.64 \pm 0.59^{\mathrm{a}}$ & $5.89 \pm 1.24^{\mathrm{a}}$ & $4.83 \pm 0.67^{\mathrm{a}}$ \\
\hline \multicolumn{8}{|l|}{$\Delta \mathbf{E}$} \\
\hline Control & $53.06 \pm 1.03^{\mathrm{a}}$ & $53.47 \pm 1.56^{\mathrm{a}}$ & $57.77 \pm 1.21^{\mathrm{a}}$ & $58.31 \pm 1.13^{\mathrm{ab}}$ & $62.88 \pm 0.62^{\mathrm{b}}$ & $63.54 \pm 0.83^{\mathrm{a}}$ & $62.89 \pm 1.62^{\mathrm{a}}$ \\
\hline US-VP & $54.48 \pm 1.12^{\mathrm{a}}$ & $54.44 \pm 1.61^{\mathrm{a}}$ & $57.11 \pm 1.93^{\mathrm{a}}$ & $56.58 \pm 1.77^{\mathrm{ab}}$ & $60.11 \pm 1.14^{\mathrm{a}}$ & $61.21 \pm 1.24 \mathrm{a}^{\mathrm{b}}$ & $61.52 \pm 1.44^{\mathrm{a}}$ \\
\hline US-MAP & $53.48 \pm 1.52^{\mathrm{a}}$ & $54.48 \pm 1.55^{\mathrm{a}}$ & $57.16 \pm 1.47^{\mathrm{a}}$ & $56.16 \pm 1.28^{b}$ & $59.16 \pm 1.24^{\mathrm{a}}$ & $60.62 \pm 1.47^{\mathrm{b}}$ & $61.57 \pm 1.3^{4 b}$ \\
\hline VP & $52.06 \pm 1.14^{\mathrm{a}}$ & $52.43 \pm 1.02^{\mathrm{a}}$ & $59.45 \pm 0.64^{\mathrm{a}}$ & $58.68 \pm 1.84^{\mathrm{ab}}$ & $60.07 \pm 0.83^{\mathrm{a}}$ & $62.08 \pm 1.21^{\mathrm{ab}}$ & $62.21 \pm 1.14^{\mathrm{ab}}$ \\
\hline MAP & $54.32 \pm 1.44^{\mathrm{a}}$ & $54.32 \pm 1.41^{\mathrm{a}}$ & $58.37 \pm 1.47^{\mathrm{a}}$ & $58.26 \pm 1.43^{\mathrm{a}}$ & $58.71 \pm 1.61^{\mathrm{a}}$ & $61.97 \pm 1.81^{\mathrm{ab}}$ & $61.01 \pm 1.54^{\mathrm{b}}$ \\
\hline
\end{tabular}

Means of three determinations $\pm \mathrm{SD}$; mean values in column with different letters were significantly different (Duncan’s test) at $(P<0.05)$. 


\subsection{Texture}

Texture is a complex attribute as evidenced by a large number of characteristics use to describe, texture, aroma and flavor characteristics are the main criteria used by consumer to evaluate the sensory quality of meat [27]. The evaluation of texture makes use of instrumental as well as sensory methods. Instrumental methods are easier and quicker to carry out, enable standardization and repeatable measurements, and require a smaller number of qualified
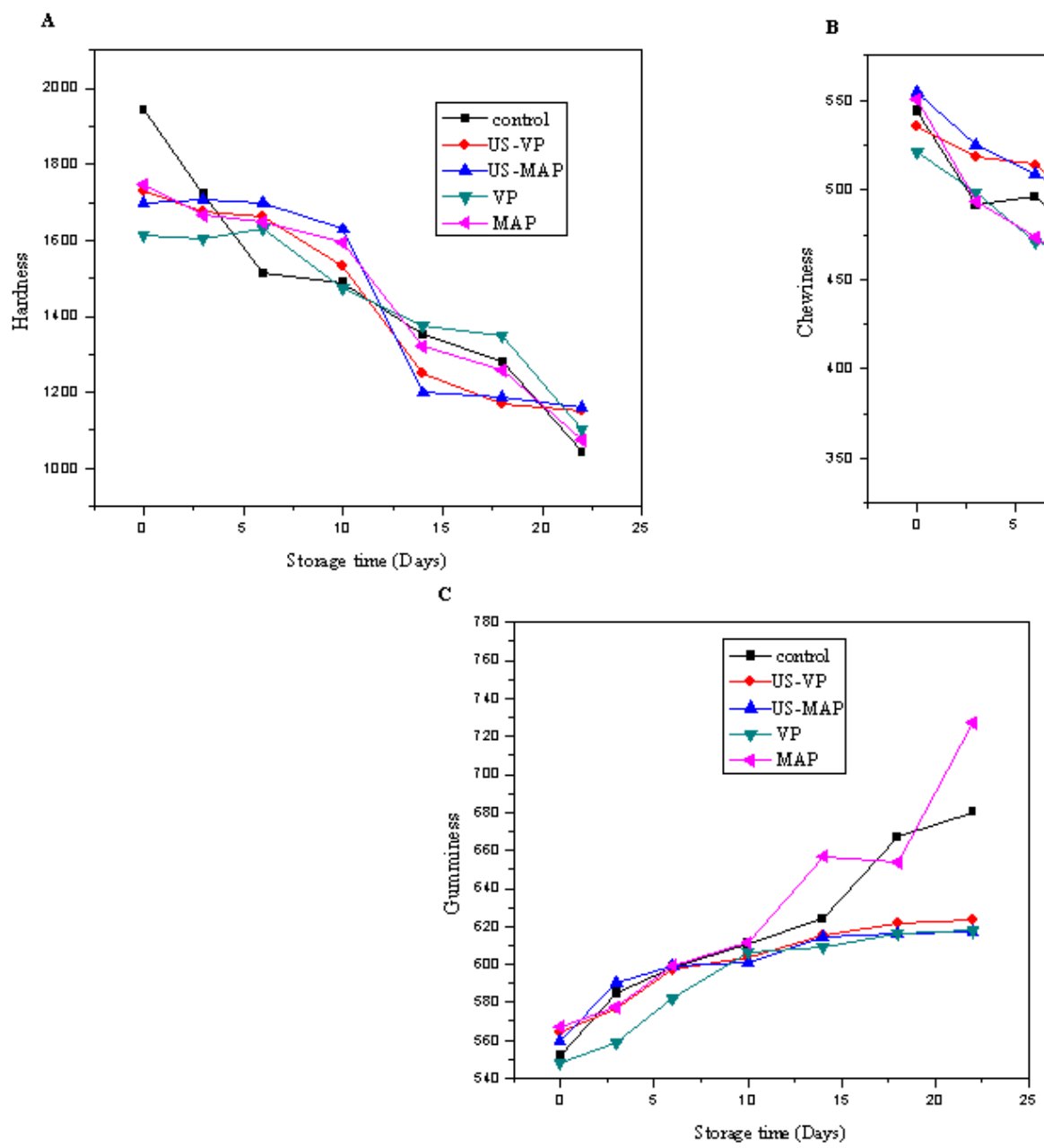

Figure 5. (A) Hardness (N), (B) gumminess $(\mathrm{N} \times \mathrm{mm})$ and $(\mathrm{C})$ chewiness $(\mathrm{N} \times \mathrm{mm})$ of meat stored after different types of treatments during storage at $4{ }^{\circ} \mathrm{C}$ for 22 days

But in vacuum package, foods maintain their texture and appearance, because microorganisms such as bacteria mold and yeast cannot grow in a vacuum [17]. Cohesiveness and chewiness are defined as how well the product withstands a second deformation relative to how it behaved under the first and the difficulty in chewing a product respectively. Cohesiveness is a measure of the degree of difficulty in breaking down the internal structure of the meat. All samples had the highest hardness at 0 day, and then samples gradually decreased with an increase in storage period. Kerr et al. (2005) suggested that the presence of texture-modifying extenders may reduce binding among the proteins rather than the water binding property of the extenders.

\subsection{Microbial Studies}

Microbial contamination refers to microorganisms directly or indirectly transferred onto a carcass or edible staff than sensory methods [28]. Texture profiles analysis of the samples as measured by a texture analyzer are shown in Figure 5.

The low intensity ultrasound treatment $\left(1.55 \mathrm{Wcm}^{-2}\right.$ for 8.16 or $24 \mathrm{~min}$ ) of vacuum packaged beef muscles had no effect on textural properties [23]. There are several main differences when using different preservation methods, for example foods maintain their freshness and flavor 3-5 times longer than with preservation storage methods in MAP, because they don't come in contact with oxygen.

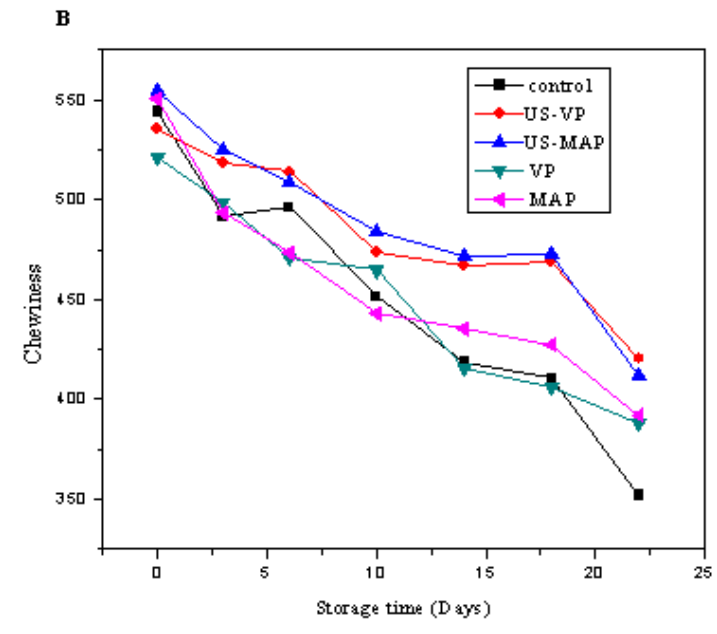

offal; hence, contaminating microflora means those microorganisms present as a consequence of such transmission. The humans used since ancient times different ways to save and keep quality of meat such as the use of salts to reduce or stop the deterioration of meat one of this salts sodium acetate, it may have added as a preservative (to prevent bacterial growth and promote longer shelf life).

As can be seen in Table 2, the initial plate count agar (PCA) values of the beef meat samples at 0 day were $2.807 \times 10^{4}, 2.731 \times 10^{4}, 2.750 \times 10^{4}, 2.739 \times 10^{4}$ and $2.991 \times 10^{4}$ for US-VP, US-MAP, VP, MAP and control treatments respectively, while the contamination increased to $2.881 \times 10^{7}, 1.354 \times 10^{7}, 1.018 \times 10^{7}, 2.322 \times 10^{7}, 2.227 \times$ $10^{7}$ for control, US-VP, US-MAP, VP and MAP, respectively, after 22 days of aerobic storage at $4{ }^{\circ} \mathrm{C}$. Fontana et al. (2006) found that, the total bacterial counts reached $10^{5} \mathrm{CFU} / \mathrm{g}$ at $2^{\circ} \mathrm{C}$ after 14 days of the storage 
period. The major sources of the initial microflora found on fresh beef are the slaughter animals themselves, the process workers, and the processing environment.

The maximum number of Lactic acid bacteria (LAB) was also observed at 22 days on control, US-VP, USMAP, VP and MAP treatments. The initial numbers of $\mathrm{LAB}$ at 0 day were $1.768 \times 10^{3}, 1.831 \times 10^{3}, 1.818 \times 10^{3}$, $1.845 \times 10^{3}, 1.836 \times 10^{3}$ for control, US-VP, US-MAP, VP and MAP treatments, respectively. The growth LAB increased with an increase in storage time, these results were in good agreement with that observed by [7]. They reported that the $\mathrm{LAB}$ counts increased from $10^{2}$ to $10^{6}$ CFU g ${ }^{-1}$ after 14 days at $8^{\circ} \mathrm{C}$ and 6 weeks at $2^{\circ} \mathrm{C}$. The load of LAB in control samples increased from $10^{2}$ to about $10^{6}$ CFU g ${ }^{-1}$ during the whole storage time, after 32 days [30]. In addition, our results regarding LAB counts were rather lower than that reported by [2], their result showed that, counts of $10^{7}$ to $10^{8} \mathrm{CFU} \mathrm{g}{ }^{-1}$ for vacuum-packaged beef stored for 6 to 8 weeks at temperatures between $1.5^{\circ} \mathrm{C}$ and $4^{\circ} \mathrm{C}$ may occur both in a dissociated and an undissociated form, dependent on $\mathrm{pH}$ [2]. Under anaerobic conditions of chilled storage with elevated levels of carbon dioxide, while the slower growing lactic acid bacteria are encouraged, the growth of aerobic spoilage microflora is discouraged [14].
LAB grows slowly at chill temperatures. Even when the count is high (100 million per g) they do not produce unpleasant odors and the product is still in good condition [17]. Lactic acid bacteria could grow to 10-100 million per $\mathrm{g}$ after about 6 weeks of storage. They will stay at this level for the rest of the life of the product but do not produce signs of spoilage until several weeks after the maximum population of bacteria is reached. Joes (2004) reported that, during storage, dominant LAB populations were observed to be totally displaced by succeeding strains after 4 weeks storage. Vacuum-packed meat is stored in the absence of oxygen and the microorganisms mentioned above (e.g. Pseudomonas) have restricted growth. Instead, the bacterial population will consist mainly of lactic acid bacteria. These should be the predominant organisms present in significant numbers if the low oxygen atmosphere is maintained, $\mathrm{pH}$ of the meat remains below 5.8, and temperature is controlled below $4^{\circ} \mathrm{C}$.

There was an increase in the number of Enterobacteriaceae from $1.845 \times 10^{3}, 1.831 \times 10^{3}, 1.736$ $\mathrm{x} 10^{3}, 1.690 \times 10^{3}$ and $1.563 \times 10^{3}$ for control, US-VP, USMAP, VP and MAP treatments, at 0 day to $2.209 \times 10^{6}$, $1.418 \times 10^{6}, 1.625 \times 10^{6}, 2.054 \times 10^{6}, 1.931 \times 10^{6}$ at 22 th day of storage, respectively.

Table 2. Changes of microbial association of meat stored after different types of treatments during storage at $4{ }^{\circ} \mathrm{C}$ for 22 days

\begin{tabular}{|c|c|c|c|c|c|c|}
\hline & & Control & US-VP & US-MAP & VP & MAP \\
\hline \multirow{3}{*}{0 day } & $P C A$ & $2.991 \times 10^{4} \pm 0.45$ & $2.807 \times 10^{4} \pm 0.36$ & $2.731 X 10^{4} \pm 0.46$ & $2.750 \times 10^{4} \pm 0.95$ & $2.732 \times 10^{4} \pm 0.47$ \\
\hline & $L A B$ & $1.768 \times 10^{3} \pm 0.17$ & $1.831 \times 10^{3} \pm 0.12$ & $1.818 \times 10^{3} \pm 0.11$ & $1.845 \times 10^{3} \pm 0.18$ & $1.836 \times 10^{3} \pm 0.14$ \\
\hline & Bacterioaceae & $1.845 \times 10^{3} \pm 0.14$ & $1.831 \times 10^{3} \pm 0.17$ & $17.36 \times 10^{3} \pm 0.14$ & $1.690 \times 10^{3} \pm 0.11$ & $1.563 \times 10^{3} \pm 0.22$ \\
\hline \multirow{3}{*}{3 days } & $P C A$ & $4.377 X 10^{4} \pm 0.11$ & $3.627 X 10^{4} \pm 0.31$ & $3.459 \times 10^{4} \pm 0.48$ & $3.327 \times 10^{4} \pm 0.42$ & $3.354 X 10^{4} \pm 0.29$ \\
\hline & $L A B$ & $4.081 \times 10^{3} \pm 0.29$ & $2.577 \times 10^{3} \pm 0.16$ & $2.959 \times 10^{3} \pm 0.42$ & $2.504 \times 10^{3} \pm 0.53$ & $2.854 \times 10^{3} \pm 0.38$ \\
\hline & Bacterioaceae & $3.104 \times 10^{3} \pm 0.20$ & $2.204 \times 10^{3} \pm 0.18$ & $1.718 \times 10^{3} \pm 0.11$ & $1.722 \times 10^{3} \pm 0.21$ & $1.759 \times 10^{3} \pm 0.28$ \\
\hline \multirow{3}{*}{6 days } & $P C A$ & $2.531 \times 10^{5} \pm 0.32$ & $1.850 \times 10^{5} \pm 0.11$ & $1.894 \times 10^{5} \pm 0.14$ & $2.181 \times 10^{5} \pm 0.21$ & $2.095 \times 10^{5} \pm 0.23$ \\
\hline & $L A B$ & $2.145 \times 10^{4} \pm 0.22$ & $5.818 \times 10^{3} \pm 0.16$ & $3.740 \times 10^{3} \pm 0.27$ & $4.681 \times 10^{3} \pm 0.25$ & $3.977 \times 10^{3} \pm 0.13$ \\
\hline & Bacterioaceae & $1.46810^{4} \pm 0.11$ & $3.609 \times 10^{3} \pm 0.29$ & $2.128 \times 10^{3} \pm 0.32$ & $3.790 \times 10^{3} \pm 0.48$ & $3.101 \times 10^{3} \pm 0.34$ \\
\hline \multirow{3}{*}{ 10days } & $P C A$ & $3.340 \times 10^{6} \pm 0.32$ & $2.505 \times 10^{5} \pm 0.24$ & $2.472 \times 10^{5} \pm 0.19$ & $28.45 \times 10^{5} \pm 024$ & $2.454 \times 10^{5} \pm 0.25$ \\
\hline & $L A B$ & $2.886 \times 10^{4} \pm .30$ & $1.972 \times 10^{4} \pm 0.21$ & $1.768 \times 10^{4} \pm 0.28$ & $1.950 \times 10^{4} \pm 0.32$ & $1.827 \times 10^{4} \pm 0.27$ \\
\hline & Bacterioaceae & $2.095 \times 10^{4} \pm 0.37$ & $1.613 \times 10^{4} \pm 0.25$ & $1.640 \times 10^{4} \pm 0.19$ & $1.882 \times 10^{4} \pm 0.31$ & $1.450 \times 10^{4} \pm .34$ \\
\hline \multirow{3}{*}{ 14days } & PCA & $2.404 \times 10^{7} \pm 0.49$ & $1.995 \times 10^{6} \pm 0.56$ & $1.895 \times 10^{6} \pm 0.38$ & $2.217 \times 10^{6} \pm 0.43$ & $1.751 \times 10^{6} \pm 0.29$ \\
\hline & $L A B$ & $3.168 \times 10^{5} \pm 0.21$ & $1.878 \times 10^{5} \pm 0.28$ & $1.754 \times 10^{5} \pm 0.24$ & $1.922 \times 10^{5} \pm 0.19$ & $1.600 \times 10^{5} \pm 0.10$ \\
\hline & Bacterioaceae & $2.395 \times 10^{5} \pm 0.34$ & $1.381 \times 10^{5} \pm 0.27$ & $1.522 \times 10^{5} \pm 0.19$ & $1.313 \times 10^{5} \pm 0.27$ & $1.109 \times 10^{5} \pm 0.20$ \\
\hline \multirow{3}{*}{ 18days } & $P C A$ & $2.750 \times 10^{7} \pm 0.66$ & $2.145 \times 10^{6} \pm 0.57$ & $1.945 \times 10^{6} \pm 0.34$ & $2.304 \times 10^{7} \pm 0.39$ & $2.156 \times 10^{6} \pm 0.49$ \\
\hline & $L A B$ & $1.968 \times 10^{6} \pm 0.24$ & $1.572 \times 10^{6} \pm 0.22$ & $1.609 \times 10^{6} \pm 0.29$ & $1.822 \times 10^{6} \pm 0.31$ & $1.904 \times 10^{6} \pm 0.45$ \\
\hline & Bacterioaceae & $1.718 \times 10^{6} \pm 0.19$ & $1.304 \times 10^{6} \pm 0.23$ & $1.245 \times 10^{6} \pm 0.29$ & $1.522 \times 10^{6} \pm 0.43$ & $1.614 \times 10^{6} \pm 0.02$ \\
\hline \multirow{3}{*}{ 22days } & $P C A$ & $2.881 \times 10^{8} \pm 0.72$ & $1.354 \times 10^{7} \pm 0.63$ & $1.018 \times 10^{7} \pm 0.33$ & $2.322 \times 10^{7} \pm 0.58$ & $2.227 \times 10^{7} \pm 0.49$ \\
\hline & $L A B$ & $2.209 \times 10^{6} \pm 0.52$ & $1.418 \times 10^{6} \pm .37$ & $1.625 \times 10^{6} \pm 0.43$ & $2.054 \times 10^{6} \pm 0.52$ & $1.931 \times 10^{6} \pm 0.40$ \\
\hline & Bacterioaceae & $1.995 \times 10^{6} \pm 0.67$ & $1.120 \times 10^{6} \pm 0.37$ & $1.413 \times 10^{6} \pm 0.39$ & $1.804 \times 10^{6} \pm 0.46$ & $1.472 \times 10^{6} \pm 0.51$ \\
\hline
\end{tabular}

Means of three determinations \pm SD; mean values in column with different letters were significantly different (Duncan’s test) at ( $P<0.05)$.

This result is agreement with that observed by [30], they found that, Enterobacteria growth showed viable counts higher than $10^{6} \mathrm{CFU} \mathrm{g}^{-1}$ after 22 days of storage.

LAB and Enterobacteriaceae, at the beginning of storage (day 0 ) were near each other but with the progress of the storage period. LAB became higher than Enterobacteriaceae, this observation may due to the fact that LAB secreted some inhibitory substance for other microbial growth. Nielsen et al. (1990) reported that, the bacteriocin reduced the number of bacteria attaching to the meat by as much as $2.7 \log$ cycles after 7 days and 1.2 log cycles after 28 days.

\subsection{Sensory Evaluation}

The scores of the acceptance test provided more definitive answers on the differences between the samples. Table 3 shows the average scores assigned by tasters for the color, flavor, texture and overall appearance attributes of fresh beef meat samples. 
Table 3. Sensory panel evaluation of meat stored after different types of treatments during storage at $4{ }^{\circ} \mathrm{C}$ for 22 days

\begin{tabular}{|c|c|c|c|c|c|c|}
\hline & & Control & US-VP & US-MAP & VP & MAP \\
\hline \multirow{4}{*}{ 3day } & color & $5.12 \pm 0.99^{b}$ & $5.37 \pm 0.91^{\mathrm{b}}$ & $6.75 \pm 0.88^{\mathrm{a}}$ & $5.87 \pm 0.83^{\mathrm{ab}}$ & $5.5 \pm 1.06^{\mathrm{a}}$ \\
\hline & texture & $5.62 \pm 0.91^{\mathrm{a}}$ & $5.87 \pm 0.99^{\mathrm{a}}$ & $6.62 \pm 0.91^{\mathrm{a}}$ & $6.00 \pm 0.92^{\mathrm{a}}$ & $6.00 \pm 0.92^{\mathrm{a}}$ \\
\hline & flavor & $5.12 \pm 0.99^{\mathrm{a}}$ & $5.00 \pm 0.75^{\mathrm{a}}$ & $6.00 \pm 0.75^{\mathrm{a}}$ & $5.00 \pm 0.93^{\mathrm{a}}$ & $5.25 \pm 1.06^{\mathrm{a}}$ \\
\hline & Overall acceptability & $5.25 \pm 0.78^{\mathrm{a}}$ & $5.75 \pm 0.88^{\mathrm{a}}$ & $6.12 \pm 0.83^{\mathrm{a}}$ & $5.25 \pm 0.71^{\mathrm{a}}$ & $5.37 \pm 1.06^{\mathrm{a}}$ \\
\hline \multirow{4}{*}{ 6days } & color & $4.37 \pm 0.91^{b}$ & $5.00 \pm 0.92^{\mathrm{ab}}$ & $5.87 \pm 0.99^{\mathrm{a}}$ & $5.12 \pm 0.83^{b}$ & $5.37 \pm 1.03^{\mathrm{ab}}$ \\
\hline & texture & $4.75 \pm 0.88^{b}$ & $5.12 \pm 0.99^{\mathrm{ab}}$ & $5.87 \pm 0.83^{\mathrm{a}}$ & $5.62 \pm 1.06^{\mathrm{ab}}$ & $5.75 \pm 1.06^{\mathrm{ab}}$ \\
\hline & flavor & $4.5 \pm 0.92^{b}$ & $1.15 \pm 0.83^{\mathrm{ab}}$ & $5.5 \pm 0.91^{\mathrm{a}}$ & $5.00 \pm 0.92^{\mathrm{ab}}$ & $5.12 \pm 0.83^{\mathrm{ab}}$ \\
\hline & Overall acceptability & $4.8 \pm 0.75^{b}$ & $5.22 \pm 0.99^{\mathrm{ab}}$ & $5.91 \pm 0.83^{\mathrm{a}}$ & $5.37 \pm 1.06^{\mathrm{ab}}$ & $5.50 \pm 0.75^{\mathrm{ab}}$ \\
\hline \multirow{4}{*}{ 10days } & color & $4.87 \pm 0.87^{\mathrm{b}}$ & $5.75 \pm 0.81^{\mathrm{a}}$ & $5.25 \pm 0.31^{\mathrm{a}}$ & $5.00 \pm 0.75^{\mathrm{a}}$ & $5.12 \pm 0.83^{\mathrm{a}}$ \\
\hline & texture & $4.97 \pm 1.35^{\mathrm{a}}$ & $5.25 \pm 0.75^{\mathrm{a}}$ & $5.87 \pm 0.88^{\mathrm{a}}$ & $5.37 \pm 0.75^{\mathrm{a}}$ & $5.37 \pm 1.06^{\mathrm{a}}$ \\
\hline & flavor & $4.12 \pm 1.45^{\mathrm{b}}$ & $4.62 \pm 0.89^{\mathrm{ab}}$ & $5.87 \pm 0.91^{\mathrm{a}}$ & $4.87 \pm 1.24^{\mathrm{ab}}$ & $5.12 \pm 1.24^{\mathrm{ab}}$ \\
\hline & Overall acceptability & $4.62 \pm 0.78^{b}$ & $5.75 \pm 0.81^{\mathrm{ab}}$ & $5.75 \pm 0.83^{\mathrm{a}}$ & $5.37 \pm 0.78^{\mathrm{ab}}$ & $5.50 \pm 0.92^{\mathrm{ab}}$ \\
\hline \multirow{4}{*}{14 days } & color & $3.75 \pm 1.16^{\mathrm{d}}$ & $5.12 \pm 1.12^{\mathrm{a}}$ & $5.25 \pm 1.03^{\mathrm{a}}$ & $4.00 \pm 0.75^{\text {bd }}$ & $5.00 \pm 1.06^{\mathrm{ab}}$ \\
\hline & texture & $4.12 \pm 0.99^{\mathrm{a}}$ & $5.01 \pm 0.91^{\mathrm{a}}$ & $5.12 \pm 0.92^{\mathrm{a}}$ & $4.5 \pm 0.74^{\mathrm{a}}$ & $4.42 \pm 0.84^{\mathrm{a}}$ \\
\hline & flavor & $3.12 \pm 1.17^{\mathrm{b}}$ & $4.62 \pm 0.91^{\mathrm{a}}$ & $5.00 \pm 0.95^{\mathrm{a}}$ & $4.75 \pm 0.88^{\mathrm{a}}$ & $4.87 \pm 1.12^{\mathrm{a}}$ \\
\hline & Overall acceptability & $3.12 \pm 0.99^{b}$ & $5.25 \pm 0.88^{\mathrm{a}}$ & $5.01 \pm 1.06^{\mathrm{a}}$ & $3.87 \pm 0.87^{\mathrm{b}}$ & $4.82 \pm 0.81^{\mathrm{a}}$ \\
\hline \multirow{4}{*}{18 days } & color & $2.12 \pm 0.83^{\mathrm{d}}$ & $4.50 \pm 0.92^{\mathrm{b}}$ & $5.5 \pm 0.75^{\mathrm{a}}$ & $3.12 \pm 0.99^{c}$ & $4.00 \pm 0.83^{\mathrm{b}}$ \\
\hline & texture & $3.37 \pm 0.91^{\mathrm{d}}$ & $4.87 \pm 0.83^{\mathrm{ab}}$ & $5.62 \pm 0.91^{\mathrm{a}}$ & $4.37 \pm 0.74^{b}$ & $4.37 \pm 0.91^{\mathrm{b}}$ \\
\hline & flavor & $2.00 \pm 0.75^{\mathrm{c}}$ & $4.12 \pm 0.99^{b}$ & $5.25 \pm 0.88^{\mathrm{a}}$ & $3.75 \pm 0.88^{b}$ & $3.62 \pm 0.91 b$ \\
\hline & Overall acceptability & $2.12 \pm 0.90^{\mathrm{d}}$ & $5.12 \pm 0.64^{\mathrm{a}}$ & $5.62 \pm 0.91^{\mathrm{a}}$ & $2.87 \pm 0.83^{\text {bd }}$ & $3.87 \pm 0.83^{\mathrm{b}}$ \\
\hline \multirow{4}{*}{22 days } & color & $1.87 \pm 0.83^{\mathrm{d}}$ & $4.37 \pm 091^{\mathrm{b}}$ & $4.12 \pm 0.64^{\mathrm{a}}$ & $3.12 \pm 1.35^{c}$ & $4.00 \pm 0.92^{\mathrm{b}}$ \\
\hline & texture & $3.12 \pm 0.99^{c}$ & $4.87 \pm 0.83^{\mathrm{ab}}$ & $4.37 \pm 0.91^{\mathrm{b}}$ & $3.87 \pm 0.83^{b}$ & $4.37 \pm 0.91^{\mathrm{b}}$ \\
\hline & flavor & $1.87 \pm 0.83^{\mathrm{c}}$ & $4.87 \pm 0.83^{\mathrm{b}}$ & $4.87 \pm 0.84^{\mathrm{a}}$ & $3.62 \pm 1.06^{\mathrm{b}}$ & $4.22 \pm \pm 1.06^{\mathrm{b}}$ \\
\hline & Overall acceptability & $2.12 \pm 0.99^{c}$ & $5.00 \pm 092^{\mathrm{a}}$ & $5.12 \pm 0.62^{\mathrm{a}}$ & $3.50 \pm 0.92^{c}$ & $4.75 \pm 0.74^{\mathrm{b}}$ \\
\hline
\end{tabular}

Means of three determinations $\pm \mathrm{SD}$; mean values in column with different letters were significantly different (Duncan’s test) at ( $P<0.05)$.

Color is a major influence on the visual appeal of meat rather than on quality. The color of meat is primarily dependant on the concentration and chemical state of the pigment myoglobin. Color appeared in most of the period of storage there was a significant difference between the standard sample and other samples. Sensory test shows the difference in color is unaccepted by panel. All samples showed slight significant different from 3 days and the control sample showed moderate accept in 3 and 6 days but not to accept the panelist at the end of the storage period. While US-MAP and US-VP treatment was the best compared with other treatments which showed the highest degree of acceptance until the end of the storage. In texture there were some significant differences between samples, but most days storage were a few degree difference storing beef in vacuum package or MAP retards development of chemical markers of flavor deterioration volatile compounds generated by microbial growth on stored, refrigerated meat are major components of offodors which signal the end of shelf-life. The undesirable flavor was not attributed to microbial storage, and the undesirable flavor was described as rancid by several panelists. Showed a control sample of unacceptance since the third day of storage. Rhee et al. (1996) reported that, the rate of decline in species-specific flavor intensity and the rate of increase in "cardboard" flavor intensity are fastest during the first three days of refrigerated storage.

The difference in overall-acceptance was significantly between all treatments, especially at the end of the storage period. Where US-MAP treatment was accepted while the control was unaccepted. In general, according to the results of sensory test, found that US-MAP treatment was the best compared with the other treatments, while the control sample is unacceptable at the end of the storage period.

\section{Conclusions}

In this study we found that US-MAP treatment gave the best results compared with other samples while samples US-VP and MAP medium quality results either control or VP samples were lower quality at the end of the storage period and unacceptable for panelist. Thus using ultrasound, sodium acetate combined with MAP or vacuum package gives better results for keeping and storage meat in the refrigerator temperature.. Ultrasound combined with MAP showed the highest panelists acceptance during the storage. Results showed deterioration in the properties of the microbial and physical characteristics quality of the control samples compared with other samples during the storage.

\section{Acknowledgements}

This work has been supported by the "973" National Basic Research Program of China (No. 2012CB720804), key laboratory of industrial Biotechnology Ministry of Education (KLIB-KF201109), Program for New Century Excellent Talents in Jiangnan University, and Priority Academic Program Development of Jiangsu Higher Education Institutions. 


\section{References}

[1] Kim, Y.S.( 2001). Chapter 24 Meat Production. In Meat Science and Application, Hui, E.H. et. al (red.). A. Marcel Dekker.

[2] Blixt, Y.- Borch, E. (2002). Comparison of shelf life of vacuumpacked pork and beef. Meat Sci. 60: 371-378.

[3] Jayasoorita, S.D.- Bhandari, B.R.-Torley, P. - D’arcy, B.R.( 2004). Effect of high power ultrasound waves on properties of meat: a review. Int. J. Food Prop. 7, 2, 301-319.

[4] Awad, T. S.- Moharram, H. A.- Shaltout, O. E.- Asker D.Youssef M M. (2012). Applications of ultrasound in analysis, processing and quality control of food: A review Food Research International 48 (2012) 41-427.

[5] Feng, H.- Yang, W. - Hielscher, T.( 2008). Power ultrasound. Food Science and Technology International, 14(5), 433.

[6] Lee, Y.L.- Cesario, T.- Owens, J.- Shanbron, E. - Thrupp, L.D. (2002). Antibacterial activity of citrate and acetate. Nutrition, 18: 665-666.

[7] Fontana, C. -Cocconcelli, P. S.- Vignolo, G. (2006). Direct Molecular Approach to Monitoring Bacterial Colonization on Vacuum-Packaged Beef. 145, T4000ILC.

[8] Skandamis, P. N. - Nychas, G. J.( 2002). Preservation of fresh meat with active and modified atmosphere packaging conditions International Journal of Food Microbiology 79. 35-45.

[9] Fernando, G. D.- Nychas, G. J. E.- Peck, M. W.- Ordonez, J. A. (1995). Growth/survival of psychrotrophic pathogens on meat packaged under modified atmospheres. Int. J. Food Microbiol. 28, 221-232.

[10] Dolatwski, Z. J.- Stadink, J.( 2007). Application of ultrasound in food technology. Acta Sci. Pol., Technol. Aliment. 6(3) 2007, 8999.

[11] European commission. :Health and consumer protection direction directorate -general Directorate C - Scientific Opinions C2 Management of scientific committees II. (2001). scientific cooperation and networks Scientific Committee on Food SCF/CS/ADD/MSAd/204.

[12] Ockeman, H. W. (1985). Quality control of post- mortem muscles tissue 13th Edn. The ohio state university, colombus, oh.

[13] Zakrys-waliwander, P. I. - O’sullivan, M.G.- O’neill, E.E. - Kerry, J.P.(2012). The effects of high oxygen modified atmosphere packaging on protein oxidation of bovine $\mathrm{M}$. longissimus dorsi muscle during chilled storage. Food Chemistry 131-527-532.

[14] Boles, J. A. - Swan, J. E.(1996). Effect of post-slaughter processing and freezing on the functionality of hot-boned meat from young bull. Meat Science, 44, 11-18.

[15] Lundstrom, K. - Malmfors, G. (1985). Variation in Light Scattering and Water HoldingCapacity along the Porcine Longissimus dorsi muscle. Meat Science, 15(4): 203-214.

[16] Mery, D.- Pedreschi, F. - Leon, J.( 2006). Color measurement in $\mathrm{L}^{*} \mathrm{a} \mathrm{b}^{*}$ units from RGB digital images, Food Research International 39. 1084-1091.

[17] Viana, E.S.- Gomide, L.A.M.- Vanetti, M.C.D. (2005). Effect of modified atmospheres on microbiological, color and sensory properties of refrigerated pork Meat Science 71, 696-705.
[18] Renerre, M. - Mazuel, J. P. (1985). Relations entre méthodes de measures instrumentaleset sensorielles de la couleour de la viande. Sciences des Aliments, 5, 541-557.

[19] Wicklund, S. E.- Hocorayan, C.- Ryan, K J- Mckeith, F. K.Mcfarlane, B. J. - Brewer, M. S.( 2005). Aging and enhancement effects on quality characteristics of beef strip steaks. J. Food Sci. 70: S242-S248.

[20] Matulis, R. J.- Mckeith, F. K., Suther L.- J. W. - Brewer, M. S.( 1995). Sensory characteristics of frankfurters as affected by fat, salt, and pH. Journal of Food Science, 60, 42-47.

[21] Apple, J.- Kegley, E. B.- Galloway, D. L.- Wistuba, T. J.- Rakes, L. K. (2005). Duration of restraint and isolation stress as a model to study the dark-cutting condition in cattle. Journal of Animal Science, 83, 1202-1214.

[22] Drummond, L. S.- Sun, D. W.( 2005). Feasibility of water immersion cooking of beef joints: Effect on product quality and yield. J. Food Eng. 77, 289-294.

[23] Jamal, N.- Muchienje, V.- Chimonyo, M.- Strydom, P. E.-Dzama, K. -Raata, J.G.(1991). Cooking loss components of beef from Nguni, Bonsmara and Angus steers, African Journal of Agricultural Research Vol. 3 (6), pp. 416-420.

[24] Pathak, V.- Sigh, V.P. - Sangjay,Y.( 2011). Ulterasound as modern Tool for Carcass Evaluation and meat Processing. ISSN 2071-7113.

[25] Jakobesn, M- Bertelesn, G.(2000). Color stability and lipid oxidation of fresh beef. Development of a response surface model for predicting the effects of temperature, storage time and modified atmosphere compositionMeat Science, 54, 49-57.

[26] John, L.- Comforth, D.- Charles, E.- Srheim, O.- Pettee, B. C. Whitier, D. R.( 2005). Colour and thiobarbituric acid values of cooked top sirloin steaks packaged in modified atmospheres of $80 \%$ oxygen, or $0.4 \%$ carbon monoxide, or vacuum. Meat Science, 69, 441-449.

[27] Gorraiz, C.- Beriain, M.J.- Chasco, J. - Iraizoz, M. (2000). Young ruminants in Mediterranean system, Journal of sensory studes 15: 137-150.

[28] Green, M. L.- Marshall, R. J. - Brooker, B.E.( 1985). Instrumental and sensory texture assessment and fracture mechanisms of Cheddar and Cheshire cheeses. J Texture. Stud 16: 351-364.

[29] Kerr, W. L.- Wang, X. - Choi, S. G.( 2005). Physical and sensory characteristics of low-fat Italian sausage prepared with hydrated oat. Journal of Food Quality, 28, 62-77.

[30] Danilo, E.- Ilario, F.- Antonietta, L. S.- Gianluiigi, M.- Sergio, G.Paolo, M.- Francesco, V.( 2009). Development of spoilage microbiota in beef stored in nisin activated packaging. 137-143.

[31] Joes, R.J. (2004). Observations on the succession dynamics of lactic acid bacteria populations in chill-stored vacuum-packaged beef Microbiology and Food Safety, Agresearch, Private Bag 3123, Hamilton, New zealand. international journal of food microbiology 90 273-282.

[32] Nilelsen, J. W.- Dickson, J. S.- Crouse, J. D.( 1990). Use of a Bacteriocin Produced by Pediococcus acidilactici To Inhibit Listeria monocytogenes Associated with Fresh Meat Roman L, Applied and environmental microbiology, p. 2142-2145.

[33] Rhee, K.S.- Anderson, L.M.- Sams, A.R.( 1996). Lipid oxidation potential of beef, chicken, and pork. J. Food Sci. 611: 8-12. 